\title{
ENVIRONMENTAL PROTECTION AND THE GENERALIZED SYSTEM OF PREFERENCES: A LEGAL AND APPROPRIATE LINKAGE?
}

\author{
Stephanie Switzer*
}

\begin{abstract}
This article will question the legality of measures of environmental 'conditionality' in the Generalized System of Preferences [GSP] of the European Community [EC]. ${ }^{1}$ The GSP is a GATT/WTO ${ }^{2}$ authorized scheme which permits developed nations to grant non-reciprocal tariff preferences in favour of developing countries. ${ }^{3}$ The objectives of the GSP are primarily development-oriented in that it aims to increase the export earnings of developing countries, promote their industrialization and accelerate rates of economic growth. ${ }^{4} \mathrm{~A}$ recent case taken in the WTO examined the legal contours of the grant of tariff preferences and it is in the light of this that this article will examine the so-called 'special incentive arrangements' of the reformed EC GSP which offers additional tariff preferences to developing countries on the 'condition' that they adhere to specified standards of environmental protection.
\end{abstract}

* The author would like to thank Joe McMahon for useful feedback he provided on an original draft of this article. Any errors are the author's own.

1 The legal base for the GSP is Art 133 EC. Since action is taken under the EC pillar, the term European Community/Communities shall be used. In addition, Art XI of the WTO Agreement (n6) on 'original membership' refers specifically to the 'European Communities' and not the European Union. The terms European Community and European Communities shall thus be used interchangeably throughout the body of this article.

2 The conceptual underpinnings of the GSP, however, can be traced to the United Nations Conference on Trade and Development (UNCTAD) and more particularly, its first Secretary General, Dr Raul Prebisch. See R Prebisch, 'Towards a New Trade Policy for Development: Report by the Secretary-General of the United Nations Conference on Trade and Development' (United Nations, New York, 1964). Dr Prebisch argued that it was essential for developing countries to diversify their economic base and emphasized the importance of export oriented growth through industrialization. In relation, Prebisch contended that preferential treatment for the industrial exports of developing countries could assist their domestic industries to overcome initial problems such as high start up costs. Preferences would guarantee a wider product market for the goods of developing countries and economies of scale would be realized which would in turn enable the lowering of costs.

${ }^{3}$ For a relatively up-to-date overview of the GSP system please see Santos et al, 'Generalized System of Preferences in General Agreement on Tariffs and Trade/World Trade Organisation: History and Current Issues’ (2005) 39 Journal of World Trade 637.

${ }^{4}$ Resolution 21 (II), in, Final Act and Report of UNCTAD II, Annex 1 (United Nations, New York, 1968). 
Given the legal uncertainty that currently exists with regard to measures of environmental conditionality in GSP schemes, this article shall attempt to provide a detailed and comprehensive statement in relation to this complex area of law. Part II provides a brief summary of the history of 'conditionality' in trade relations and examines its usage within the GSP. Part III details the development of the GSP of the European Communities and examines the legislative background to environmental conditionality in the GSP. Part IV focuses upon the WTO dispute between India and the EC (hereinafter EC-Tariff Preferences) and details the findings of the WTO dispute settlement body. Part V examines the environmental conditionality of the new EC GSP in the light of the jurisprudential pronouncements in EC-Tariff Preferences and attempts to assess its legality, while Part VI looks to the future of the GSP and suggests a number of proposals for reform.

\section{CONDITIONALITY AND TRADE RELATIONS}

Relations between States in the world trade order are based upon the twin pillars of non-discrimination and reciprocity of concessions. The demand for non-discrimination manifests itself in a most-favoured-nation (MFN) clause contained in Article I.1 of the General Agreement on Tariffs and Trade (GATT), ${ }^{6}$ one of the so-called 'covered agreements' of the WTO. The MFN clause ensures formal equality of treatment between contracting parties to the GATT/WTO by mandating that any advantage or privilege extended to the product of one country must be extended 'immediately and unconditionally' to the goods of all other countries party to the WTO. Reciprocity of concessions between States relates to the premise that one must give in order to receive. Reciprocity demands that any tariff reduction by a country must be 'paid' for by a reciprocal, though not necessarily identical, concession on the part of other contracting States. Equality of treatment is therefore mirrored by reciprocity of concessions.

There are numerous exceptions to this demand for formal equality and reciprocity. One of these exceptions is the Generalized System of

\footnotetext{
5 Council Regulation 980/2005/EC Applying a Scheme of Generalized Tariff Preferences [2005] OJ L 169/1.

${ }^{6}$ General Agreement on Tariffs and Trade 1994, 15 Apr 1994, Marrakesh Agreement Establishing the World Trade Organization, Annex 1A, THE LEGAL TEXTS: THE RESUlTs OF THE URUGUAY ROUND OF MULTILATERAL TRADE NEGOTIATIONS 17 (1999), 1867 UNTS 187, 33 ILM 1153 (1994) [hereinafter GATT 1994]. The WTO was created as a result of Uruguay Round of multilateral trade negotiations. These negotiations were structured around the GATT 1947, a provisional trade 'agreement' or protocol drafted to ensure the reduction of tariff barriers between parties. GATT 1947 remained essentially unchanged from the date of its signing. The GATT 1947 was updated during the Uruguay Round and became GATT 1994 which is itself one of the core or 'covered agreements' of the WTO.
} 
Preferences (GSP) which, as noted above, permits developed nations to grant non-reciprocal tariff preferences in favour of developing countries without extending such advantages to developed countries. The GSP is granted legal authority by way of an instrument called the Enabling Clause, ${ }^{7}$ a GATT document which allows Members to derogate from their obligations under Article 1.1 of GATT 1994 in order to accord differential and more favourable treatment to developing countries. Paragraph 2(a) of the Enabling Clause permits developed countries, 'notwithstanding the provisions of Article 1 of the GATT ... (to) accord preferential treatment to products originating in developing countries in accordance with the Generalized System of Preferences without according such treatment to other Members'. Footnote 3 to the Enabling Clause defines 'Generalized System of Preferences' by reference to the system outlined in a 1971 GATT waiver $^{8}$ which provided the original legal footing within the GATT for the establishment of 'generalized, non-reciprocal and non-discriminatory preferences beneficial to the developing countries'.

In contrast to the obligation contained in Article I.1 GATT which requires MFN treatment to be extended unconditionally to all other Member countries, there is no provision in the Enabling Clause to the effect that the grant of preferences must be 'unconditional'. Bartels has described how GSP beneficiaries have been subject to 'positive' and 'negative' conditionalities. 9 Positive conditionality functions as an incentive to the extent that additional preferences are granted to beneficiaries in return for compliance with certain standards of behaviour. Negative conditionality operates to withdraw tariff preferences from existing GSP beneficiaries for infractions of certain conditions as set out by the preference-granting State. Positive conditionality therefore accords to the use of the GSP as a carrot while negative conditionality is reflective of the utilization of preferences as a method of punishment.

Acts of negative conditionality are synonymous with the GSP system of the United States which contains various mandatory and discretionary criteria applicable to developing country eligibility. ${ }^{10}$ The operation of negative

7 Differential and More Favourable Treatment, Reciprocity and Fuller Participation of Developing Countries (28 Nov 1979) BISD 26S/203, GATT Doc L/4903 (1979).

${ }^{8}$ Generalized System of Preferences Waiver Decision (25 June 1971) BISD 18S/24, GATT Doc L/3545 (1971).

9 L Bartels, 'The WTO Enabling Clause and Positive Conditionality in the European Community’s GSP Program’ (2003) 6 Journal of International Economic Law 507, 508.

${ }^{10}$ For an overview of the current US regime instituting the GSP please see, US Generalized System of Preferences Guidebook (2006) available at < http://www.ustr.gov > (last accessed 30 Sept 2006) and, for example, 19 USC § 2462(b)(2) listing mandatory criteria which each country must fulfil before being designated a GSP beneficiary. Countries must not be 'dominated by international communism', must not harbour or offer sanctuary to 'any individual who has committed an act of international terrorism' and must have taken steps or be taking steps towards implementing internationally recognized labour standards. 19 USC $§ 2462$ (c) lists 'discretionary' criteria applicable to beneficiaries of the US GSP. 
conditionality under the United States' GSP has resulted in the withdrawal of tariff concessions from 'problematic States' as punishment for their lack of cooperation. Such arguments regarding United States use of the GSP are far from novel. ${ }^{11}$ In a study by Drahos of United States trade action against developing countries in the GATT between 1984 and 1993, a systemic pattern emerged that 'almost every developing country that opposed the US at the GATT ended up being listed for bilateral attention by the US', either through the section $301^{12}$ process or its GSP programme. ${ }^{13}$

Negative conditionality ${ }^{14}$ exists in the provisions of the current GSP scheme of the $\mathrm{EC},{ }^{15}$ although the Community has in general shied away from withdrawing tariff preferences from developing countries otherwise eligible for tariff preferences. The first and only withdrawal of preferences under the EC scheme occurred in 1997 when the Union of Myanmar was suspended from receipt of tariff preferences due to alleged forced labour practices. ${ }^{16}$ A Regulation was promulgated in December 2006 authorizing temporary withdrawal of GSP concessions from Belarus for alleged violation of the right to collective bargaining and freedom of association. This Regulation entered into force on 21 June $2007 .^{17}$

11 See generally R Bhala, 'The Limits of American Generosity' (2003) 29 Fordham Journal of International Law 299. See also Jones, 'Generalized System of Preferences: Background and Renewal Debate' (update 24 Jan 2007), Congressional Research Service, Library of Congress, Order Code RL33663 which notes that some US supporters of the GSP take the view that conditionality 'provide[s] the United States with international political leverage that can be used to preserve US foreign and commercial interests' at CRS-24.

12 Unilateral enforcement measures have previously been authorized under s 301 of the Trade Act of 1974 which accords the United States Trade Representative the authority to 'withdraw, limit, or suspend [duty free treatment]' in a 'case in which the act, policy, or practice also fails to meet eligibility criteria for receiving duty free treatment' applicable to the grant of GSP concessions, 19 USC $\$ 2411$ (c)(1)(C).

${ }^{13}$ P Drahos and M Braithwaite, 'Hegemony Based on Knowledge: The Role of Intellectual Property' in J Chen and G Walker (eds) Balancing Act: Law, Policy and Politics in Globalisation and Global Trade (The Federation Press, Leichhardt, 2004) 213.

14 Council Regulation (EC) 980/2005 Applying a Scheme of Generalized Tariff Preferences [2005] OJ L 169/1 Art 16 authorizes temporary withdrawal in the event of; (a) serious and systematic violations of human and labour rights as defined in Part A of Annex III to the Regulation, (b) export of goods made by prison labour, (c) failure to control export of illegal drugs and/or failure to comply with international conventions on money laundering, (d) unfair trading practices affecting the EC, (e) infringement of agreements pertaining to sustainable management of fishery stocks.

${ }_{15}$ Negative conditionality was formally introduced by way of Council Regulation (EC) 3281/ 94 Applying a four-year Scheme of Generalized Tariff Preferences (1995-8) in Respect of Certain Industrial Products Originating in Developing Countries [1994] OJ L 348/1 Art 12 and Council Regulation [EC] 1256/96 Applying Multiannual Schemes of Generalized Tariff Preferences from 1 July 1996 to 30 June 1999 in Respect of Certain Agricultural Products Originating in Developing Countries [1996] OJ L 166/1 Art 12.

16 Council Regulation (EC) 552/97 Temporarily withdrawing Access to Generalized Tariff Preferences from the Union of Myanmar [1997] OJ L 85/8.

17 Council Regulation (EC) 1933/2006 Temporarily withdrawing Access to the Generalized Tariff preferences from the Republic of Belarus [2006] OJ L 405/35. 
The history of the preference system of the EC has thus been one of avoidance of 'GSP-linked sanctions. ${ }^{18}$ However, in the last decade increased emphasis has been placed upon positive conditionality within the GSP of the EC. The next section will examine the development of positive conditionality within the EC GSP. This will provide a necessary background to the dispute of EC-Tariff Preferences which examined the permissibility of conditionality within the GSP.

\section{DEVELOPMENT OF THE GSP OF THE EUROPEAN COMMUNITIES}

The previous section examined the positive and negative aspects of conditionality. This section will trace the development of the GSP of the EC and elucidate upon the emergence of a policy of positive conditionality whereby additional tariff preferences are granted to developing countries in return for adherence to certain standards relating to the promotion of 'sustainable development'. Particular attention will be paid to the development of sustainable development within EC law more generally and the role of environmental protection as one of its key components.

The original GSP of the [then] European Economic Community ${ }^{19}$ was instituted in 1971 via the adoption of six regulations covering industrial products and a separate regulation governing preferential treatment in agricultural goods. ${ }^{20}$ These regulations administered a scheme of preferential tariff treatment for developing country products which was set to run for 10 years until $1981 .^{21}$ From the start, the GSP was depicted as part of a wider policy of assistance and cooperation between the EEC and the developing world. Therefore, in contrast to other

countries, both developing and developed, [who] considered the generalized preferences as no more than limited measures of trade policy, the Community has always taken the view that they are an instrument for development cooperation. $^{22}$

18 S Arnau, The Generalized System of Preferences and the World Trade Organization (Cameron May, London, 2002) 270.

19 Products covered by the now defunct European Coal and Steel Community [ECSC] were covered by two separate regulations promulgated by the Council of the European Communities, see Yusuf, Legal Aspects of Trade Preferences for Developing States (Kluwer, The Hague, 1982) 120.

${ }^{20}$ Council Regulations (EEC) [1972] OJ L142/1 et seq. See also the original communication of the Commission detailing the original 'offers' of the GSP scheme of the EEC, Commission des Communautés Européennes, La mise en application de l'offre de la communauté en matière de préférences généralisées a octroyer en faveur des exportations d'articles manufactures et des produits semi-finis des pays en voie de développement SEC (71) 1000 (15 Mar 1971).

21 The 1971 temporary GATT waiver which provided for the original imposition of the GSP was limited in time to ten years from 1971 to 1981, see BISD (n 8). The 10-year time limit of the original EEC GSP was thus merely a reflection of the temporary GATT waiver.

${ }^{22}$ Commission Communication on The Future Development of the European Community's Generalized Tariff Preferences COM(75)17 final (3 Feb 1975). 
Despite the explicit linkage between the GSP and development policy, the preference scheme of the EEC established from the start an elaborate system of quantitative import limitations which rather curtailed the value of the preferential tariff treatment on offer. These limitations took the form primarily of tariff ceilings and tariff quotas and their operation was such that the degree of preferential treatment accorded to single products as well as to the trade of individual beneficiaries could vary from year to year. As such, each of the regulations governing the operation of the GSP was subject to yearly change and amendment, undermining the capacity of the GSP to provide for trade expansion given the uncertainty inherent in tariff treatment from year to year.

The GSP of the European Communities was subsequently reauthorized, with few changes, in 1981 and was scheduled to run until 1991. A 10-year review of the operation of the GSP from 1981 to 1991 was originally scheduled for 1 January 1991 to revise and update the workings of the GSP. However, the review was postponed pending the conclusion of the Uruguay Round, which culminated in the formation of the WTO. ${ }^{23}$ The GSP was renewed in $1990^{24}$ but aside from slight technical changes, no overarching review was forthcoming until 1994.

In 1994, the EC GSP scheme for industrial products was substantially amended. ${ }^{25}$ The amendments made provision for the GSP to apply to a four year period rather than the one-year application period of previous schemes. Quantitative limitations on products otherwise eligible for GSP treatment were removed and replaced with a system of 'tariff modulation.' This system categorized products into four classes of 'sensitivity', the sensitivity of a product being determined by reference to the manufacturing situation for that same product in the European Community. ${ }^{26}$ Tariff modulation according to sensitivity divided products into goods into 'very-sensitive', 'sensitive', 'semi-sensitive', and 'non-sensitive' product groupings. With a few exceptions, eligible countries received tariff reductions of 15 per cent, 30 per cent,

23 Commission Background Note on the Community's Generalized System of Preferences (GSP) MEMO/94/35 (2 June 1994).

${ }^{24}$ Regulation (EEC) 3831/90 [1990] OJ L 370/1; Regulation [EEC] 3832/90, OJ [1990] L 370/39; Regulation (EEC) 3833/90 [1990] OJ L 370/86; Regulation (EEC) 3834/90 [1990] OJ L 370/121; Regulation (EEC) 3835/90 [1990] OJ L 370/126; and Regulation (EEC) 3900/91 [1991] OJ L 368/11.

25 Council Regulation (EC) 3281/94 Applying a Four-year Scheme of Generalized Tariff Preferences (1995 to 1998) in Respect of Certain Industrial Products Originating in Developing Countries [1994] OJ L 348/1.

26 European Commission Director General for Trade, 'User's Guide to the European Union's Scheme of Generalized Tariff Preferences' (Feb 2003), available at < http://ec.europa.eu/trade/ issues/global/gsp/gspguide.htm > (last accessed 28 Jan 2007), note that this Guide has not been updated and does not deal with the operation of the current GSP scheme. The definition of sensitivity is, however, unaffected. 
65 per cent, and 100 per cent, respectively, off MFN tariff duty applicable to the goods concerned. ${ }^{27}$

In a 1994 Communication on the 'role of the GSP: 1995-2004', 28 the European Commission noted that while the traditional legal basis for the GSP had been [current] Article 133 EC [ex Article 113 EC] which governs the common commercial policy, the GSP was really a development tool, and as such, 'must be placed at the service of development in the broader senseembracing social and environmental concerns ...' ${ }^{29}$ The Commission thus proposed the introduction of 'special incentive' mechanisms which would supplement the benefits available under the general GSP scheme and aim to provide 'positive inducements and logical components of development policy in that they reflect the idea of social progress and protection of the environment as aspects of, rather than preconditions for, sustainable development' ${ }^{30}$ The Commission proposal put forward the idea of providing additional margins of preference to developing countries willing to implement certain social and environmental policies as part of a wider goal to promote sustainable development.

The notion of sustainable development is primarily an international construct, the genesis of which can be traced to the 1972 United Nations Conference on the Human Environment. ${ }^{31}$ The results of this Conference stressed that efforts towards environmental protection could not be divorced from issues such as economic and social development. In 1992, the United Nations convened a conference in Rio de Janiero on the environment and development which reaffirmed the principles expounded in 1972 and underscored international commitment to the pursuit of sustainable development. While the idea of sustainable development has produced a myriad of definitions, the best-known attempt to craft a definition for the concept is that of the Brundtland Commission Report ${ }^{32}$ which defined sustainable development as development that 'meets the needs of the present without compromising the ability of future generations to meet their own needs'.

The concept of sustainable development has grown and adapted since the circulation of the Brundtland Commission's Report and has come to represent

27 Council Regulation (EC) 3281/94 Art 2; Council Regulation (EC) 2820/98 Applying a Multiannual Scheme of Generalized Tariff Preferences for the Period 1 July 1999 to 31 December 2001 [1998] OJ L 357/1 Art 2.

${ }_{28}$ Commission Communication from the Commission to the Council and the European Parliament, Integration of the Developing Countries into the International Trading System: Role of the GSP COM(94)212 final (1 June 1994).

29 ibid 3.

30 ibid 11.

31 United Nations Conference on the Human Environment, 'Report of the United Conference on Human Environment' (June 1972) A/Conf 48/14 and Corr 1, Chap II sect. B; see also United Nations Conference on Environment and Development, 'Rio Declaration on Environment and Development' (June 1992), A/CONF.151/26 (Vol I).

32 Published as Brundtland Commission, Our Common Future (OUP, Oxford, 1987). 
the culmination of a policy triangle embracing trade, the environment and economic development. ${ }^{33}$ Thus, advocates of sustainable development favour

open economic relations and economic growth, because poverty is a prime cause of environmental degradation, and because economic growth provides greater resources (and more favourable attitudes) for environmental protection. At the same time, the basic notion is that economic growth must be sustainable for the benefit of future generations. ${ }^{34}$

The first formal reference to sustainable development within the Treaties establishing the EC/EU was introduced by the Treaty on European Union [TEU] negotiated at Maastricht in 1991, which amended Article 2 EC to introduce the promotion of 'sustainable development' into Community competence. Article B (present Article 2) of the TEU similarly lists the achievement of 'balanced and sustainable development' to be one of the objectives of the Union. Article 130(r)(2) EC [present Article 174(2)] was also amended at Maastricht so that the obligation that environmental protection shall be a 'component' of other Community policies was transformed into a requirement that it be integrated into the very 'definition and implementation' of Community policy. As a result of the momentum for sustainable development launched at Maastricht, the fifth European Environmental Action Programme approved in 1993 adopted the concept of sustainable development pronounced in the Brundtland Report and thereby attempted to lay the groundwork for the implementation of the concept at Community level. ${ }^{35}$ The conclusion of the treaty of Maastricht also introduced for the first time an explicit legal basis for the conclusion of agreements aimed at development cooperation ${ }^{36}$ and identified 'sustainable economic and social development of [developing countries] and their gradual integration into the world economy, as priority objectives. $^{37}$

33 S Gaines, 'International Trade, Environmental Protection and Development as a Sustainable Development Triangle' (2002) 11 Review of European Community and International Environmental Law 259, 261.

34 K Abbot, "Economic" Issues and Political Participation: The Evolving Boundaries of International Federalism' (1996-7) 18 Cardozo Law Review 971, 979.

35 Resolution of the Council and the Representatives of the Governments of the Member States, meeting within the Council of 1 February 1993 on a Community programme of policy and action in relation to the environment and sustainable development - a European Community programme of policy and action in relation to the environment and sustainable development [1993] OJ C138/1, as noted in M O'Neill, 'Agriculture, the EC and the WTO: A Legal Critical Analysis of the Concepts of Sustainability and Multifuctionality' (2002) 4(3) Environmental Law Review 144, n 26.

36 Title XX [ex XVII] EC, see E Fierro, The EU's Approach to Human Rights Conditionality in Practice (Martinus Nijhoff, The Hague, 2003) 28.

37 EC Commission Background Note on the European Union's New Generalized System of Preferences (GSP) Scheme MEMO/95/1 (19 Jan 1995), referring to Art 177 (1) and (2) EC [ex Art $130 \mathrm{u}]$. 
While the GSP is currently promulgated on the basis of the common commercial policy, ${ }^{38}$ it was iterated above that it has generally been considered a 'tool' with which to assist in the development of developing countries. The introduction at Maastricht of a link between trade and the integration of developing countries into the world economy on the one hand, and sustainable and social development on the other, thus afforded the Community significant political capital to introduce the concept of 'sustainable development' into the GSP. This is particularly so given that in 1993, the United Nations Conference on Trade and Development [UNCTAD], an organization traditionally depicted as the 'secretariat of the south' recommended at its eighth conference in Cartagena the 'mainstreaming' of sustainable development into policies to foster the growth of developing countries. The eighth UNCTAD conference noted that sustainable development encompasses 'such key issues as patterns of economic activity, modes of consumption, the persistence of poverty, the quality of development and necessary adaptation of domestic and international economic management' ${ }^{39}$ It was recognized that poverty reduction, strategies to facilitate growth and protection of the environment were mutually reinforcing policies. ${ }^{40}$ It was against such a background that the EC opted to introduce the so-called 'special incentives arrangements'.

The 'special incentive arrangements' ${ }^{41}$ were formally introduced in 1998 and offered an additional margin of preference to developing countries

38 Common Commercial Policy is found in Title IX [ex VII] EC Treaty. The legal basis for the promulgation of the GSP was the subject of a legal challenge in 1987. The European Court of Justice [ECJ] in Case 45/86 Commission v Council [1987] ECR 1493 upheld Art 133 [ex Art 113] EC as the correct legal basis, despite the development objectives of the grant of preferences.

39 UNCTAD, 'Proceedings of the United Nations Conference on Trade and Development, 8th Session at Cartagena de Indias Colombia’ (1993) UN Doc TD/364/Rev.I para 38.

40 ibid para 63.

41 The establishment of these special incentive arrangements was provided for in Arts 7 and 8 of Council Regulations (EC) 3281/94 and (EC) No 1256/96; however, the introduction of these arrangements was delayed by the need for a report into the 'intensity and modalities' of the planned scheme which was tasked to be completed by the Commission and presented to the Council by 1997. The report was completed in June 1997; see Commission Report to the Council pursuant to Art 7 (2) of Council Regulations 3281/91 and 1256/96 on the scheme of generalized preferences: Summary of the work conducted within the ILO, OECD and the WTO on the link between international trade and social standards, COM(97)260 final (2 June 1997). Subsequently, the Commission issued a proposal to activate the special incentive arrangements; see Commission Proposal for a Council Regulation (EC) applying the special incentive arrangements concerning labour rights and environmental protection provided for in Arts 7 and 8 of Council Regulation (EC) 3281/94 and 1256/96 applying the scheme of generalized tariff preferences in respect of certain industrial and agricultural products originating in developing countries COM(97)534/4 (29 Oct 1997). The special incentive arrangements were finally introduced by way of Council Regulation (EC) No 1154/98 applying the special incentive arrangements concerning labour rights and environmental protection provided for in Arts 7 and 8 of Regulations (EC) No 3281/94 and (EC) 1256/96 Applying Multiannual Schemes of Generalized Tariff Preferences in Respect of Certain Industrial and Agricultural Products Originating in Developing Countries [1998] OJ L 160/1. This Regulation was set to expire on the date of expiry of Regulations (EC) 3281/94 and (EC) 1256/96. Regulation (EC) 3281/94 was set to expire on 31 December 1998 but was extended 
determined by the European Community to be in compliance with certain labour and environmental policy standards. ${ }^{42}$ The condition relating to environmental protection mandated eligibility seeking countries to 'effectively apply' the standards of the International Tropical Timber Organization relating to the sustainable management of tropical forests. Paralleling the introduction of the special incentives arrangements was the incremental creation of a 'development acquis' within European policy. ${ }^{43}$ Environmental protection was central to this development acquis and manifested itself in the institution of a Council Regulation promoting the full integration of the environmental dimension in the development process of developing countries. ${ }^{44}$ An aspect of this environmental dimension was a concern for the sustainable management and conservation of tropical forests, ${ }^{45}$ hence its inclusion within the special incentive arrangements of the EC GSP.

The special incentive arrangements were subsequently incorporated into a new Council Regulation EC 2820/98 applying a multiannual scheme of generalized tariff preferences from 1 July 1999 to 31 December $2001{ }^{46}$ The separate preference schemes relating to agricultural products and industrial products were also merged by this Regulation. ${ }^{47}$ The GSP scheme of the European Communities was amended and updated in 2001 by Regulation $2501 / 2001^{48}$ and scheduled to run from 1 January 2002 to 31 December 2004. This Regulation formed the basis of a dispute between India and the European Communities and it is to this dispute that we turn to elucidate upon the particular legal requirements of the grant of preferences.

\section{THE DISPUTE OF EC-TARIFF PREFERENCES}

The previous section considered the incremental development of environmental conditionality and its intrinsic linkage to sustainable development

until 30 June 1999 by Council Regulation EC 2820/98. Applying a Multiannual Scheme of Generalized Tariff Preferences from 1 July 1999 to 31 December 2001 [1998] OJ L 357/1.

42 Council Regulation (EC) 1154/98 Arts 8-21.

43 E Morgera and G Duran, 'Enlargement and EU Development Policy: An Environmental Perspective' (2004) 13 Review of European Community and International Environmental Law $152,154$.

44 EC Regulation 2493/2000 of 7 November 2000 on measures to promote the full integration of the environmental dimension in the development process of developing countries [2000] OJ L288/1.

45 EC Regulation 2494/2000 of 7 November 2000 on measures to promote the conservation and sustainable management of tropical forests and other forests in developing countries [2000] OJ L288/6.

46 Council Regulation (EC) 2820/98 Arts 8-21.

47 The agricultural and industrial schemes were merged for reasons of simplicity and to make the GSP easier to use, see Commission Proposal for a Council (EC) Regulation applying a scheme of generalized tariff preferences for the period of 1 January 1999 to 31 December 2001 COM(98)521 (16 Sept 1999) 2.

48 Council Regulation (EC) 2501/2001 Applying a Scheme of Generalized Tariff Preferences for the period from 1 January 2002 to 31 December 2004 [2001] OJ L 346/1. 
within the GSP scheme of the European Communities. This section shall elaborate upon the WTO dispute of EC-Tariff Preferences and will examine the legislative and political background to the dispute as well as offer a detailed analysis of the findings of the Appellate Body.

\section{A. Background to the Dispute}

The WTO GSP dispute between India and the European Communities centred upon the granting of additional tariff preferences to certain developing countries to assist them in their fight against drug trafficking and production. The disputed 'drug arrangements' were one of five tariff preference schemes available to developing countries under EC Council Regulation 2501/2001: ${ }^{49}$

(i) The General Arrangements;

(ii) Special Incentive Arrangements for the protection of labour rights;

(iii) Special Incentive Arrangements for the protection of the environment;

(iv) Special Arrangements for the least developed countries; and

(v) Special Arrangements to combat drug production and trafficking (the 'Drug Arrangements').

India was a recipient of tariff preferences under the General Arrangements. Of the four remaining arrangements under the EC GSP scheme, each scheme offered separate eligibility requirements and differed with respect to the extent of tariff reductions offered, product coverage and the conditions upon which tariff preferences could be reduced or removed. While India had initially indicated concern with the special incentive schemes for protection of the environment and labour rights, it ultimately limited the scope of its complaint to the Drug Arrangements, while reserving the right to bring some future complaint regarding the environmental and labour special incentive schemes. $^{50}$

The nature of the Drug Arrangements was such as to limit the offer of additional preferences to a closed list of twelve countries; Bolivia, Colombia, Costa Rica, Ecuador, El Salvador, Guatemala, Honduras, Nicaragua, Pakistan, Panama, Peru, and Venezuela. The so-called 'preferred' list of 12 received tariff preferences over and above those offered to recipients under the General Arrangements.

The difference between the preferences granted under the Drug Arrangements and those under the General Arrangements related to both the depth of the tariff cut offered as well as the products covered under each scheme. With regard to the tariff cut available, the Drug Arrangements offered

${ }^{49}$ Council Regulation (EC) 2501/2001.

50 Panel Report, European Communities: Conditions for the Granting of Tariff Preferences to Developing Countries, WT/DS246/R, adopted 202004 para 1.4 (hereinafter, EC-Tariff Preferences Panel). 
duty-free treatment to products referred to in Annex IV and subject to ad valorem duties, or a reduction of duty to a rate of 3.6 per cent. Products subject to specific duties were entitled under the Drug Arrangements to either duty free treatment or, at most, the levying of a duty limited to 16 per cent of the customs value. In relation to products covered by both the General Arrangements and the Drug Arrangements and listed as 'sensitive' ${ }^{51}$ under column G of Annex IV to the Regulation, the 12 preferred countries were granted duty-free treatment while products originating from beneficiaries of the General Arrangements were merely entitled to a tariff reduction. In relation to the product coverage of each scheme, Column D of Annex IV of the Council Regulation details the products covered under the Drug Arrangements. The list of products covered under the Drug Arrangements is more extensive than applicable under the General Arrangements. Thus, for products included under the Drug Arrangements but not under the General Arrangements, the preferred 12 received duty-free treatment while countries eligible under the General Arrangements were subject to the full duties payable under the Common Customs Tariff. ${ }^{52}$

The argument set out by India in the dispute contained two main elements;

1. The Drug Arrangements instituted by the European Communities were inconsistent with Article 1.1 of GATT 1994.

2. Drug Arrangements could not be justified by reference to the Enabling Clause. $^{53}$

As noted above, the recipients of 'Drug Arrangements' were primarily Latin American countries of the Andean and Central American region. After the events of 11 September 2001, however, Pakistan was also added to the list of countries eligible to receive additional tariff preferences under the Drug Arrangements of the European Communities' GSP. While Pakistan certainly was and indeed still is afflicted by significant problems relating to the production and trafficking of drugs through its territory, it would appear that the primary motivation behind the advancement of additional tariff preferences to Pakistan under the EC's special incentive arrangements to combat drugs was to secure its acquiescence and support in the invasion of Afghanistan and, more broadly, the 'war on terror'. ${ }^{54}$ An EU memo on the issue states that:

In recognition of Pakistan's changed position on the Taliban regime and its determination to return to democratic rule in 2002, the Commission has stepped

51 With the exception of products listed in CN codes 0306 13, 17041091 and 17041099.

52 EC-Tariff Preferences Panel paras 2.7-2.8.

53 ibid para 3.1 .

54 Use of the GSP as a response to terrorism is not unprecedented; for example, the United States GSP contains a clause to the effect that eligibility would be denied to any country that purported to 'aid or abet, by granting sanctuary from prosecution, any individual or group that has committed an act of international terrorism', 19 USC 2462(b)(2). 
up the EU's assistance to Pakistan (up to $€ 100$ million in 2001/2002). A new Co-operation Agreement was signed at the occasion of the visit of President Prodi and PM Verhofstadt to Pakistan on the 24 November 2001, where they also met up with President Musharraf. On 16 October, The Commission presented a package of trade measures designed to significantly improve access for Pakistani exports to the EU ... In return, Pakistan will improve access to its markets for EU clothing and textile exporters. The package gives Pakistan the best possible access to the EU short of a Free Trade Agreement by making it eligible for the new Special Generalized System of Preferences Scheme for countries combating drugs. $^{55}$

India was naturally concerned at the prospect of concessions estimated to be worth around $€ 150$ million a year (through the elimination of duties) $)^{56}$ being granted to its nearest rival. India's claim in EC-Tariff Preferences thus centred upon the inclusion of Pakistan within the EC's special incentive arrangements to combat drugs and the very real possibility of trade diversion which accompanied it.

While the dispute of EC-Tariff Preferences did not inquire into the 'history' of the Drug Arrangements under the GSP scheme of the European Communities, an investigation of the chronological development of the link between tariff preferences and a desire to combat the problem of drugs reveals that until the events of 11 September 2001, the Drug Arrangements were intended to benefit a closed list of Latin American countries. Indeed, the historical development of the Drug Arrangements can be traced to 12 November 1985 when a Cooperation Agreement between the European Economic Community, on the one part, and the countries party to the General Treaty on Central American Economic Integration (Costa Rica, El Salvador, Guatemala, Honduras, and Nicaragua) and Panama was signed. ${ }^{57}$ In 1990, the European Commission produced a proposal for a regulation to extend to Bolivia, Colombia and Peru the more favourable tariff treatment ${ }^{58}$ as one part

55 EU Response to 11 September: European commission action, MEMO 02/122 (3 June 2002) $<$ http://europa.eu.int/rapid/pressReleasesAction.do?reference=MEMO/02/122\& format=HTML \&aged $=0$ \&language $=$ EN\& guiLanguage $=$ en $>$ (last accessed 25 Feb 2006), see also Commission of the European Communities, Amended Proposal for a Council Regulation applying a scheme of generalized tariff preferences for the period 1 January 2002 to 31 December 2004 COM(2001)688 final (14 Nov 2001).

56 BRIDGES/ICTSD, 'WTO Appellate Body: Differentiation Possible Under Preference Schemes' (22 Apr 2004) < http://www.ictsd.org/weekly/04-04-22/story4.htm > (last accessed 25 Feb 2007).

57 Cooperation Agreement between the European Economic Community, of the one part, and the countries parties to the General Treaty on Central American Economic Integration (Costa Rica, El Salvador, Guatemala, Honduras and Nicaragua) and Panama, of the other partDeclarations by the Community_Exchange of Letters [1986] OJ L 172/2.

${ }_{58}$ Commission Proposal to the Council for a Regulation extending to Bolivia, Colombia and Peru the generalized tariff preferences applied to certain products originating in the leastdeveloped countries and amending Regulations (EEC) Nos 3896/89, 3897/89 and 3898/89 COM(90)254 final (18 Dec 1989). 
of a three-point plan designed to assist in the battle against drugs production and trafficking being fought in the Andean producer countries of Bolivia, Colombia and Peru. The other two features of the assistance plan took the form of increased financial support and better coordination of aid. ${ }^{59}$ A Council Regulation of December 1990 subsequently granted Bolivia, Colombia, Peru and Ecuador an exemption on quantitative limitations on industrial and textile products as well as duty-free treatment on these items and duty-free treatment on a specified list of agricultural products. ${ }^{60}$

In 1991, similar efforts were made to improve the economic situation of the Central American countries of Costa Rica, El Salvador, Guatemala, Honduras, and Nicaragua as well as Panama. While these six countries were held to be not as badly affected by the problem of drugs as the Andean countries, the Commission noted three factors which made it vital for the Community to provide practical support to Central America. The Commission thereby listed the fragile peace process throughout the region occurring against a volatile social and political background, the historical political and social links between the Community and the region and finally the need to prevent the problem of drugs spreading beyond the area. ${ }^{61}$ In a Council Regulation of 16 December 1991, Common Customs Tariff duties for a majority of the agricultural products covered by Regulation 3833/90/EEC were suspended for each respective country until 31 December $1992 .{ }^{62}$ In the 1994 Communication from the Commission on the role of the GSP from 1995-2004, ${ }^{63}$ it was noted that the so-called Drug Arrangements applicable to the Andean and Central American countries should continue 'provided the countries concerned for their part continue their efforts to combat drugs and some results are achieved'. ${ }^{64}$

The Drug Arrangements were subsequently renewed by Regulation 2820/ 98/EC and Regulation 2501/2001. The latter regulation made an explicit link between social and environmental protection and additional preferences under

59 European Parliament Session Documents, Report of the Committee on Development and Cooperation on the Commission Proposal to the Council for a Regulation extending to Bolivia, Colombia and Peru the generalized tariff preferences applied to certain products originating in the least-developed countries and amending Regulations (EEC) Nos 3896/89, 3897/89, and 3898/89 of 18 December 1989 COM(90)254, A3-0225/90 (24 Sept 1990).

60 Council Regulation (EEC) 3835/90 Amending Regulations (EEC) 3831/90, (EEC) 3832/90 and (EEC) 3833/90 In Respect of the System of Generalized Tariff Preferences Applied to Certain Products originating in Bolivia, Colombia, Ecuador and Peru [1990] OJ L 370/ 126.

61 European Commission, Proposal for a Council Regulation (EEC) amending Council Regulation 3833/90 in respect of the system of generalized tariff preferences applied to certain products originating in Costa Rica, El Salvador, Guatemala, Honduras, Nicaragua, and Panama, SEC (91) 1109 (9 July 1991).

62 Council Regulation (EEC) 3900/91 Suspending Common Customs Tariff duties for products covered by Regulation (EEC) No 3833/90 and originating in Costa Rica, El Salvador, Guatemala, Honduras, Nicaragua, and Panama [1991] OJ L 368/11 Art 1.

63 ibid 12.

64 ibid 13. 
the Drug Arrangements. Thus, Article 25 of Regulation 2501/2001 established a requirement to the effect that the Commission

shall also assess each beneficiary country's [under the Drug Arrangements] (a) social development, in particular the respect and promotion of the standards laid down in the ILO Conventions referred to in the ILO Declaration on Fundamental Principles and Rights at Work, [and] (b) environmental policy, in particular the sustainable management of tropical forests.

Before the entry into force of the updated Drug Regulations contained in Regulation 2501/2001, the Commission became concerned that the Enabling Clause may not provide the necessary legal cover to ensure the compatibility of the arrangements with WTO rules. The concern related to the fact that the Arrangements were only available to a 'closed' list of countries. In 2001, the Communities applied to the WTO for a waiver to provide legal security to the Arrangements. The request recognized that 'because the special arrangements are only available to imports originating in those [limited] members, a waiver from the provisions of paragraph 1 of Article I of GATT 1994 appears necessary before they can effectively enter into force for reasons of legal certainty'. ${ }^{65}$ The Communities failed to secure this waiver but opted to go and ahead and continue with the grant of additional preferences under the Drug Arrangements. The continuance of the grant of preferences was to result in India contesting the terms of the Communities GSP within the WTO dispute settlement system.

India contended that the Enabling Clause did not absolve the European Communities from its obligation to grant MFN treatment to developing country products ${ }^{66}$ and argued that with the exception of special treatment accorded to the least developed members, the Enabling Clause could only justify preferences that were 'non-discriminatory preferences beneficial to the developing countries' (emphasis added). ${ }^{67}$ The use of the definitive article 'the' was held by India to be conclusive proof of the requirement that GSP schemes must benefit all developing countries. ${ }^{68}$

While recognizing that the Enabling Clause did not oblige any developed country to provide a scheme of preferences, India argued that it did mandate that a Member who chose to institute a preference scheme must abide by the framework for preferences described within the 1971 waiver. Any preference scheme must therefore be 'generalized, non-reciprocal and non-discriminatory'. Non-discriminatory was to be understood in its ordinary context. To discriminate was therefore held to equate to the act of

${ }^{65}$ Request for a WTO Waiver-New EC Special Tariff Arrangements to Combat Drug Production and Trafficking, 24 Oct 2001 (G/C/W/328) as cited in Panel Report, European Communities-Conditions for the Granting of Tariff Preferences to Developing Countries, WT/ DS246/R, adopted 202004, modified by Appellate Body Report, WT/DS/246/AB/R, 9.

66 ibid para 4.30 .

67 ibid para 4.35 .

68 ibid. 
making a 'distinction in the treatment of different categories or people or things' ${ }^{69}$ Since the Drug Arrangements clearly made a distinction between two categories of developing countries, India argued that the European Communities had clearly breached the terms of Article 1.1 of GATT 1994 and could not avail of the Enabling Clause as an affirmative defence since the Enabling Clause does not absolve Members from according MFN treatment to products originating in developing countries. ${ }^{70}$

The European Communities argued that the Enabling Clause excludes the applicability of Article 1.1 of the GATT $1994^{71}$ and so does not act as an 'affirmative defence' with which to justify violation. Instead, the European Communities described the Enabling Clause as a 'self standing regime' which conferred a permanent right to grant certain types of more favourable and differential treatment to developing countries, 'notwithstanding' Article 1.1 of GATT $1994 .{ }^{72}$ Therefore, the European Communities contended that not only did it not bear the burden of proof with respect to defending the Drug Arrangements, but rather India, as the complaining party, was required to establish the inconsistency of the Drug Arrangements with the Enabling Clause. $^{73}$

The European Communities also argued that the term 'developing countries' contained in paragraph 2(a) of the Enabling Clause did not impose an obligation to grant 'differential and more favourable treatment' to all developing countries on an MFN basis. ${ }^{74}$ In a related point, the European Communities contended that the term 'non-discriminatory' contained in footnote 3 to the Enabling Clause does not mandate that all developing countries be treated in an identical fashion ${ }^{75}$ but rather requires that equal situations are treated equally while unequal situations are treated differently. ${ }^{76}$ Any distinction made between countries should therefore pursue a legitimate aim and there should be sufficient nexus between the objective pursued and any distinction made. ${ }^{77}$ It follows that treating differently developing countries that are particularly affected by the problem of drugs is not 'discriminatory ${ }^{78}$ The Drug Arrangements were designed to respond to the gravity of the drug problem of each beneficiary under the scheme ${ }^{79}$ and were determined by the European Communities to be consistent with paragraph 3(c) of the Enabling Clause which refers to the 'development, financial and trade needs of developing countries' which are individual to each country. ${ }^{80}$ Since need varies between developing countries and between categories of developing countries, trade preferences such as those available under the Drug Arrangements constitute an appropriate response to the developmental needs of those countries particularly affected by the problem of drugs.

${ }^{69}$ ibid para 4.33 .

71 ibid para 4.42 .

74 ibid para 4.44(i)

${ }^{76}$ ibid para 4.65.

${ }^{79}$ ibid para 4.75 .

$$
\begin{aligned}
& 72 \text { ibid. } \\
& 77 \text { ibid. }
\end{aligned}
$$

${ }^{70}$ ibid para 4.22 .

73 ibid para 4.44.

75 ibid para 4.47.

${ }^{78}$ ibid para 4.70 .

80 ibid para 4.66. 
A WTO dispute settlement Panel established to hear the dispute subsequently upheld India's complaint. ${ }^{81}$ The Communities appealed the finding and the matter was passed to the WTO Appellate Body for its consideration.

\section{B. Appellate Body Analysis}

The Appellate Body started its analysis by looking at the relationship between Article 1.1 and the Enabling Clause and held that the Enabling Clause operates as an 'exception' to Article GATT I.1. ${ }^{82}$ The Appellate Body then considered whether the Enabling Clause could be used to justify the GSP scheme of the European Communities. It found that the phrase 'nondiscriminatory' in footnote 3 to paragraph 2(a) of the Enabling Clause did not prohibit the granting of different tariff preferences to products originating from GSP beneficiaries. It held that differentiation between developing country recipients under a GSP scheme was therefore permissible. ${ }^{83}$ The reasoning employed by the Appellate Body to support its reading of paragraph 2(a) and footnote 3 to the Enabling Clause related to the fact that 'paragraph 2(a), on its face, does not explicitly authorize or prohibit the granting of different tariff preferences to different GSP beneficiaries'. However, it added the proviso that any differentiation would only be acceptable and accord to the ordinary meaning of the term 'non-discriminatory' if identical treatment was available to all similarly situated GSP beneficiaries. ${ }^{84}$

On the facts of the dispute, the Appellate Body found that the Drug Arrangements instituted by the European Communities were discriminatory in that its 12 beneficiaries constituted a 'closed list' ${ }^{85}$ If the aim of the Drug Arrangements scheme was to respond to the 'need' of certain GSP beneficiaries with respect to the problem of illicit drug production and trafficking, ${ }^{86}$ the Drug Arrangements would have had to have been available to all developing countries similarly affected by the problem of drugs in order to satisfy the conditions of non-discrimination. ${ }^{87}$ Since adding to the list of beneficiaries entitled under the Drug Arrangements would have required an amendment to the Regulation, ${ }^{88}$ this was clearly not the case. The lack of transparency with which the European Communities operated the Drug Arrangements was also noted by the Appellate Body in respect of the fact that the Regulation did not seek to set any standards or criteria that must be fulfilled in order to qualify for inclusion under the Drug Arrangements. ${ }^{89}$ The

81 ibid paras 8.1-8.4

82 Appellate Body Report European Communities-Conditions for the Granting of Tariff Preferences to Developing Countries, WT/DS/246/AB/R adopted 20 April 2004 para 36 (hereinafter EC-Tariff Preferences Appellate).
83 ibid para 173 .
86 ibid para 179 .
84 ibid.
85 ibid para 187.
88 ibid para 185 .
87 ibid para 188.
89 ibid para 188 . 
Appellate Body therefore held that 'although the European Communities claim that the Drug Arrangements are available to all developing countries that are 'similarly affected by the drug problem', because the Regulation does not define the criteria or standards that a developing country must meet to qualify for preferences under the Drug Arrangements, there is no basis to determine whether those criteria or standards are discriminatory or not. For these reasons, we find that the European Community has failed to prove that the Drug Arrangements meet the requirement in footnote 3 that they be "nondiscriminatory'. ${ }^{90}$ The European Communities had therefore failed to justify the Drug Arrangements.

\section{CHECKLIST FOR MEASURES OF DIFFERENTIATION}

The previous section elaborated on the terms of the dispute of EC-Tariff Preferences. Based on relevant findings of this dispute, this author has constructed a 'checklist' of the considerations which the Appellate Body will likely bear in mind in assessing any future WTO challenge to measures GSP conditionality. This checklist will be utilized to assess the WTO conformity of the current EC GSP ${ }^{91}$ which was promulgated in the wake of the judgment of EC-Tariff Preferences. Particular reference will be had to measures of conditionality which seek to ensure environmental protection.

Any differentiation between developing countries must be available to all 'similarly situated' countries. ${ }^{92}$ The primary focus of the Appellate Body's judgment related to the proper interpretation to be ascribed to 'nondiscriminatory.' While the original Panel hearing of the dispute held that the term 'non-discriminatory' imposed an obligation upon GSP donor states to offer identical tariff treatment to all beneficiary developing countries (with the exception of the least developed), the Appellate Body reversed this by stating that discrimination did not arise in circumstances were identical tariff preferences were granted to all 'similarly situated' countries. The reading accorded to 'similarly situated' by the Appellate Body stated that precedence was not to be accorded to any historical, cultural or special ties between the beneficiary and granting state. As such, the Appellate Body recognized that 'one of the objectives of the 1971 Waiver Decision and the Enabling Clause was to eliminate the fragmented system of special preferences that were, in general, based on historical and political ties between developed countries and their former colonies' ${ }^{93}$ Accordingly, the linking of preferences to any 'special' relationship between parties would likely be incompatible with the

90 ibid paras $187-8$.

${ }^{91}$ Council Regulation (EC) 980/2005 Applying a Scheme of Generalized Tariff Preferences [2005] OJ L 169/1.

${ }_{92}$ EC-Tariff Preferences Appellate para 173.

93 ibid para 155. 
judgment of the Appellate Body under EC-Tariff Preferences and would require a waiver to GATT Article 1. In relation, the Appellate Body specifically noted the provision in the footnote to paragraph 2 of the Enabling Clause to the effect that

it would remain open for CONTRACTING PARTIES to consider on an ad hoc basis under the GATT provisions for joint action any proposals for differential and more favourable treatment not falling within the scope of this paragraph.

Any differentiation must be enacted as a positive response to 'need'. The Appellate Body stated that any differentiation between GSP beneficiaries must respond positively to the 'needs of developing countries.' 94 The phrase 'respond positively' is derived from the paragraph 3(c) of the Enabling Clause which mandates that treatment provided under the Enabling Clause "shall in the case of such treatment accorded by developed contracting parties to developing countries be designed and, if necessary, modified, to respond positively to the development, financial and trade needs if developing countries' (emphasis added). In examining the context for the term 'non-discriminatory', the Appellate Body ${ }^{95}$ looked to paragraph 3 (c) of the Enabling Clause and noted that the use of the word 'shall' is indicative of an obligation for developed countries providing preferential treatment under a GSP scheme to respond positively to the needs of developing countries. ${ }^{96}$ The Appellate Body adopted the OED meaning of the word and as such, "positive" is defined as "considering in or characterized by constructive action or attitudes (emphasis added).",97

The type of need to which a differential response would be appropriate is "limited to the "development, financial and trade needs.",98 The Appellate Body looked to the nature of the 'development, financial and trade needs' identified by the preference granting state and made note of the fact that developing countries may have 'development, financial and trade needs' that are subject to change. ${ }^{99}$ The changing nature and indeed understanding of such needs is best reflected with an examination of the concept of 'development' which was initially understood within the GSP as relating to economic development. Accordingly, if we look to the aims of the GSP as elucidated upon within Resolution 21(II) of second UNCTAD conference in New Delhi, ${ }^{100}$ then we discover that the rationale of preferences was primarily economic in that the GSP was tasked to increase export earnings, promote industrialization and promote economic development. However, the understanding given to development in EC-Tariff Preferences appears to move

\footnotetext{
94 ibid para 157.

96 ibid para.

97 ibid para 164.

95 ibid para 158.

9 ibid para 160.

100 Resolution 21 (II), in, Final Act and Report of UNCTAD II, Annex 1 (United Nations New York 1968).
} 
away from such a narrow understanding of development as equivalent to economic development, according an evolutionary understanding to the concept of development in that 'it is simply unrealistic to assume that such development will be in lockstep for all developing countries at once, now and for the future. ${ }^{, 101}$

The existence of a relevant need must be capable of objective assessment. The existence of a relevant developmental, financial or trade need will not be taken at face value. Rather, the particular trade need must be assessed according to an objective and not subjective standard. 'Broad-based recognition of a particular need, set out in the WTO Agreement or in multilateral instruments adopted by international organizations can act as this standard' (emphasis added). ${ }^{102}$ The reference to multilateral instruments arguably concurs with the Appellate Body's evolutionary approach to designate 'need' as recognizing that non-WTO agreements can provide the necessary reference to identifying a relevant 'need'.

There must be a 'nexus' between the need identified and the imposition of differential tariff treatment. The Appellate Body suggests that a 'sufficient nexus should exist between, on the one hand, the preferential treatment provided under the respective measure ... and, on the other hand the likelihood of alleviating the relevant "development, financial [or] trade need.", 103 The particular measure at issue must therefore be "such that it can be effectively addressed through tariff preferences' ${ }^{104}$ (emphasis added). The use of the word 'can' indicates the test to be applied is whether the measure is capable, in an objective sense, of responding to the recognized need. However, it should be noted that in its assessment of the Drug Arrangements, the Appellate Body criticized the lack of an 'indication as to how the European Communities would assess whether the Drug Arrangements provide an "adequate and proportionate response" to the needs of developing countries suffering from the drug problem'. ${ }^{105}$ There must therefore be some sort of evaluative mechanism to satisfy the requirement of 'sufficient nexus' between the recognized need and the differential treatment. The mandated GSP measure must therefore include:

Clear prerequisites or 'objective' criteria available that would allow other developing countries to be included as beneficiaries of differential tariff treatment. ${ }^{106}$

The grant of tariff treatment 'to the varying needs of developing countries [should] not impose unjustifiable burdens on other Members...this requirement applies, a fortiori, to any preferential treatment granted to one GSP beneficiary that is not granted to another'. ${ }^{107}$

101 EC-Tariff Preferences Appellate para 160.

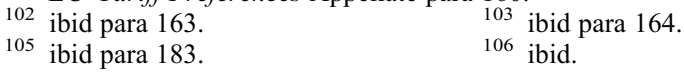

104 ibid.

107 ibid para 167. 


\section{A. Scrutinizing the new GSP of the EC}

The previous section considered the Appellate Body judgment in EC-Tariff Preferences and elaborated a 'checklist' of considerations likely to be borne in mind with respect to any future challenge to the WTO legality of conditional tariff preferences. Following a brief exposition of the procedural and substantive workings of the current GSP Regulation of the EC, this section will assess its compatibility with WTO rules as well as provide a brief commentary upon the appropriateness of the legal interpretation provided by the Appellate Body in EC-Tariff Preferences. It will be contended that the current GSP Regulation may not necessarily be compatible with the findings of the Appellate Body. It will also be argued that the Appellate Body's 'checklist' provides the donor country with considerable autonomy to designate 'need', thereby undermining the ability of developing states to assess and participate in efforts to determine their own needs.

Following the results of the WTO dispute, the European Commission presented a draft proposal for a new Council Regulation applying a scheme of tariff preferences. ${ }^{108}$ The contents of this proposal were subsequently adopted in the new GSP Regulation 980/2005. ${ }^{109}$ Authorising the grant of preferential tariffs until 31 December 2008, the new Regulation introduces three different 'arrangements' governing the grant of preferences. There is the 'general arrangement', the 'special incentive arrangement for sustainable development and good governance' and 'special arrangement for least-developed countries [LDC]'.

All GSP beneficiaries are eligible to receive the tariff preferences available under the 'general arrangements'. Customs tariff duties for non-agricultural goods marked as 'non-sensitive' are entirely suspended while ad valorem duties on goods marked as 'sensitive' are reduced by 3.5 percentage points. Specific duties applicable to sensitive goods are reduced by 30 per cent. If a sensitive good is subject to a combination of ad valorem and specific duties, only the ad valorem duty is subject to a reduction. ${ }^{110}$

The 'special arrangement for least-developed countries' provides duty-free treatment to the overwhelming majority of goods from LDCs. One group of products excluded from duty-free access is arms and ammunitions. Hence, the arrangement has come to be known as the 'Everything but Arms' [EBA] initiative. In addition, the Community market for rice and sugar is not yet fully liberalized. For these goods, incremental tariff reductions are offered with a view to full institution of duty-free treatment in 2009 .

\footnotetext{
108 Commission Proposal for Council Regulation Applying a Scheme of Generalized Tariff Preferences COM(2004)699 (20 Oct 2004).

109 Council Regulation (EC) 980/2005 Applying a Scheme of Generalized Tariff Preferences [2005] OJ L 169/1. 
The 'special incentive arrangement for sustainable development and good governance' allows for the suspension of Common Customs Tariff duties for all products listed in Annex II originating from beneficiaries of the 'special incentive' scheme. Specific duties on these products are suspended except for products for which the Common Customs Tariff duties also include ad valorem duties. A list of products excluded from the scope of the special incentive arrangements are listed in Column $\mathrm{C}$ of Annex 1 to the proposal. At the time of the Regulation's publication, no beneficiary state under this arrangement had any excluded products listed in Column $\mathrm{C}$ to Annex 1.

Eligibility for the special incentive arrangements is defined in the GSP regulation by reference to a number of criteria with two major hurdles to eligibility being of note. The first hurdle relates to ratification in that a country must have ratified and effectively implemented all the conventions relating to human rights and labour rights listed in Part 'A' of Annex III. Sixteen conventions are listed in total:

\section{Part A of Annex III}

\section{Core Human/Labour Rights UN/ILO Conventions}

1. International Covenant on Civil and Political Rights

2. International Covenant on Economic, Social, and Cultural Rights

3. International Convention on the Elimination of All Forms of Racial Discrimination

4. Convention on the Elimination of All Forms of Discrimination Against Women

5. Convention Against Torture and other Cruel, Inhuman or Degrading Treatment or Punishment

6. Convention on the Rights of the Child

7. Convention on the Prevention and Punishment of the Crime of Genocide

8. Convention concerning Minimum Age for Admission to Employment (No 138)

9. Convention concerning the Prohibition and Immediate Action for the Elimination of the Worst Forms of Child Labour (No 182)

10. Convention concerning the Abolition of Forced Labour (No 105)

11. Convention concerning Forced or Compulsory Labour (No 29)

12. Convention concerning Equal Remuneration of Men and Women Workers for Work of Equal Value (No 100)

13. Convention concerning Discrimination in Respect of Employment and Occupation (No 111)

14. Convention concerning Freedom of Association and Protection of the Right to Organize (No 87) 
Environmental Protection and The Generalized System of Preferences 135

15. Convention concerning the Application of the Principles of the Right to Organize and to Bargain Collectively (No 98)

16. International Convention on the Suppression and Punishment of the Crime of Apartheid.

In addition, a country must ratify and effectively implement at least seven (out of a total of 11) of the Conventions relating to 'the environment and governance' listed in Part B of Annex III: ${ }^{111}$

\section{Part B of Annex III}

\section{Conventions Related to the Environment and Governance Principle}

17. Montreal Protocol on Substances that Deplete the Ozone Layer

18. Basel Convention on the Control of Transboundary Movements of Hazardous Wastes and Their Disposal

19. Stockholm Convention on Persistent Organic Pollutants

20. Convention on International Trade in Endangered Species of Wild Fauna and Flora

21. Convention on Biological Diversity

22. Cartagena Protocol on Biosafety

23. Kyoto Protocol to the United Nations Framework Convention on Climate Change

24. United Nations Single Convention on Narcotic Drugs (1961)

25. United Nations Convention on Psychotropic Substances (1971)

26. United Nations Convention against Illicit Traffic in Narcotic Drugs and Psychotropic Substances (1988)

27. United Nations Convention against Corruption (Mexico)

The second hurdle listed in the GSP Regulation relates to the requirement that an eligibility seeking country should be 'vulnerable'. A vulnerable country is defined in Article 9 (3) to the Regulation as a country that 'is not classified by the World Bank as a high income country during three consecutive years, and whose five sections of its GSP-covered imports to the Community represent more than 75 per cent of its total GSP-covered imports' and 'whose GSPcovered imports to the Community represent less than $1 \%$ in value of total GSP-covered imports into the Community'. ${ }^{112}$

Bearing in mind the findings of the Appellate Body in EC-Tariff Preferences, this paper shall examine the requirements posed by the special incentive requirements for environmental protection (Part B of Annex III above) in order to make an assessment as to the legality of the provisions.

1. Any differentiation between developing countries must be available to all 'similarly situated' countries with clear prerequisites or 'objective' 
criteria available that would allow other developing countries to be included as beneficiaries of differential tariff treatment

As iterated above, the 'closed' list approach taken by the Communities in extending the 'benefits' of the Drug Arrangements to Pakistan was particularly criticized by the Appellate Body in EC-Tariff Preferences. No criteria existed whereby countries 'similarly situated' in terms of suffering similar problems relating to drug trafficking and production could benefit from the Drugs Arrangements with eligibility simply being decided a priori the promulgation of the relevant Regulations.

The 'similarly situated' requirement exists to ensure 'non-discrimination' in that 'distinguishing among similarly situated beneficiaries is discriminatory'. ${ }^{113}$ In EC-Tariff Preferences, the Appellate Body articulated the need for a transparent set of objective criteria that would allow all similarly situated countries to be added to the list of recipient states. This requirement thus outlaws de jure discrimination whereby a distinction is made between the goods of two countries on the basis of their country of origin. ${ }^{114}$ The new GSP Regulation appears to take this need for clear and objective criteria on board in its promulgation of a number of requirements applicable to developing countries seeking eligibility status:

(a) The eligibility requirement; the new GSP Regulation is a marked improvement in that it offers a transparent procedure whereby all similarly situated developing countries may benefit from additional tariff preferences with 'eligibility' being defined by reference to the two hurdles of 'vulnerability' and 'ratification'.

(b) The procedural requirement; Article 10 of the GSP Regulation provides a clear procedural system for the submission of requests by developing countries seeking to benefit from the special incentive arrangements

(c) The examination requirement; Article 11 of the GSP Regulation lists a set of steps which will be entered into in the examination of any request for additional tariff treatment.

The above requirements thus provide for a facially equal system, applicable to all developing countries seeking eligibility status. However, one point of note is that the conditions listed in the new Regulation may have a greater impact on some countries than others. While the focus of this article is on the environmental and provisions of the special incentive arrangement, it is notable that the conditions relating to 'core human and labour rights' (Part A of Annex III) have a disparate impact across the original countries listed as beneficiaries under the Regulation [as originally published]. Of the

\footnotetext{
113 EC-Tariff Preferences Appellate para 153.

$114 \mathrm{M}$ Trebilcock and R Howse, The Regulation of International Trade (Routledge, London and New York, 2005) 72.
} 
14 countries listed in the Annex I of the Regulation as beneficiaries under the special incentive arrangements, only five countries have recently [from 2005] ratified any of the listed UN/ILO conventions; Georgia, ${ }^{115}$ Guatemala, ${ }^{116}$ Moldova, ${ }^{117}$ Mongolia, ${ }^{118}$ and El Salvador, ${ }^{119}$ with the remaining nine countries having ratified the rest of the conventions many years previously. The 'burden' of ratification is thus unequally spread.

For all similarly situated countries to be able to avail of differential favourable tariff treatment elicited as a response to a particular 'need', all such countries should be able to adhere to the enunciated requirements. Thus, implicit in the pronouncements of the Appellate Body is a requirement that all similarly situated countries should have the capacity to adhere to the conditions imposed. The Appellate Body notes that

paragraph 3 (a) of the Enabling Clause to the effect that any 'differential and more favourable treatment ... shall be designed to facilitate and promote the trade of developing countries and not to raise barriers to or create undue difficulties to the trade of any other contracting parties'... requires that any positive response ... to the varying needs of developing countries not impose unjustifiable burdens of other Members. ${ }^{120}$

It is contended that for all similarly situated countries to avail of differential tariff treatment, any requirement invoked by the donor State should not be 'unjustifiably burdensome'.

The requirement that any measure of differentiation should not be unjustifiably burdensome so that all similarly situated countries are able to avail of the measure arguably accords to a de facto reading of the requirement of non-discrimination. De facto discrimination ${ }^{121}$ results when a measure is applicable to all countries but has a disparate impact upon certain States. The standard of de facto discrimination has been applied by the Appellate Body in its articulation of the precise meaning of Article II of the General Agreement on Trade in Services [GATS] which establishes a most-favoured-nation

\footnotetext{
115 International Convention on the Suppression and Punishment of the Crime of Apartheid ratified 21 March 2005, see < http://www.unhchr.ch/html/menu3/b/treaty8 asp.htm > (last accessed 25 Feb 2007).

117 ibid ratified 28 October 2005.

118 Convention concerning Minimum Age for Admission to Employment (No 138), Convention concerning the Abolition of Forced Labour (No 105) and Convention concerning Forced or Compulsory Labour (No 29) ratified 15 March 2005, see < http://www.ilo.org/ilolex/ english/newratframeE.htm > (last accessed 25 Feb 2007).

119 Convention concerning Freedom of Association and Protection of the Right to Organize (No 87) and Convention concerning the Application of the Principles of the Right to Organize and to Bargain Collectively (No 98) ratified 6 September 2006, see < http://www.ilo.org/ilolex/ english/newratframeE.htm > (last accessed 25 Feb 2007).

120 EC-Tariff Preferences Appellate para 167.

121 See Ehring, 'De Facto Discrimination in World Trade Law' (2002) 36 (5) Journal of World Trade 921 which argues that differential treatment between imports may be suitable grounds.
} 
standard in relation to trade in services. In EC-Bananas III, the Appellate Body noted that

[t]he obligation imposed by Article II is unqualified. The ordinary meaning of this provision does not exclude de facto discrimination. Moreover, if Article II was not applicable to de facto discrimination it would not be difficult ... to devise discriminatory measures aimed at circumventing the basic purpose of that Article. $^{122}$

The pronouncements of the Appellate Body in EC-Bananas III are arguably applicable here in that a system of preferences which imposes conditions of disparate impact could 'easily circumvent the basic purpose' of the GSP. This is due to the fact that the 'generalized' system of preferences was introduced to end 'special' trade relations based upon historical, colonial and political ties. ${ }^{123}$ Thus the GSP scheme of the EC must be assessed to ensure that it does not result in de facto discrimination such as to favour countries with which the preference granting state has some sort of 'special' relationship. It is worth noting that by 31 December 2008, developing country recipients under the special incentives scheme will be expected to have ratified 27 separate conventions. ${ }^{124}$ If the special incentive measures are ever challenged at WTO level, the Panel/Appellate Body would be under an obligation to enquire as to whether such an expectation is not unduly burdensome. The preamble to the GSP states that the special incentive measures are designed to assist

developing countries which due to a lack of diversification and insufficient integration into the international trading system are vulnerable while assuming special burdens and responsibilities due to the ratification and effective implementation of core international conventions on human and labour rights, environmental protection and good governance should benefit from additional tariff preferences.

Thus, the special incentives are designed to assist countries which lack diversification in their export base, are insufficiently integrated into the international trading system and are classed as vulnerable. Is limiting assistance to those countries which have the necessary resources to undertake ratification of 27 different conventions actually a response to the identified needs? The argument that additional preferences 'will pay for themselves' in terms of the competitive advantage offered is rather reduced if one considers the growing myriad of free trade agreements being negotiated by the European Community. Goods from members of FTAs generally enter duty-free, thereby trumping any tariff advantage offered under the special incentive arrangements. In addition, recent economic literature has questioned the overall benefit of the GSP in that developing country 'reliance' upon preferential

\footnotetext{
122 Appellate Body Report, European Communities-Regime for the Importation, Sale and Distribution of Bananas, WT/DS27/AB/R, adopted 251997, para 233.

123 n 93.

124 Council Regulation (EC) 980/2005 Art 9(c).
} 
tariff treatment may in fact serve to delay their integration into multilateral trading order. ${ }^{125}$

Any differentiation must be enacted as a positive response to 'need' while the type of need to which a differential response would be appropriate is 'limited to the "development, financial and trade needs"'

As iterated above, a 'positive' response to 'need' is characterized by constructive attitudes or actions. The consideration of whether an act is constructive arguably demands a process of evaluation. If we ascribe this evaluative function to dispute settlement, then the Panel or Appellate Body will be assigned a role with considerable political implications to the extent that it will be tasked to consider whether an approach which differentiates between recipients of tariff preferences is, in fact, 'constructive'.

As to the question of whether committing to a host of environmental conventions represents a 'constructive' response to a relevant development, trade or financial need, it is probably the case that the conventions represent a broad reading of the concept of 'sustainable development'. In footnote 107 of the judgment of US-Shrimp, the Appellate Body noted in obiter commentary that 'this concept [of sustainable development] has been gradually accepted as integrating economic and social development and environmental protection'. ${ }^{126}$ In the same dispute, the Appellate Body held that 'the preamble to the WTO Agreement ... acknowledges the 'objective of sustainable development'. ${ }^{127}$ In EC-Tariff Preferences, the Appellate Body confirmed that sustainable development constituted an 'objective of the WTO'. ${ }^{128}$ The link between promoting the economic growth of developing countries and sustainable development is well established in international law and an evolutionary reading of the concept of 'development' as listed in the GSP'129 would probably recognize this.

However, the question of whether 'the existence of a relevant need is capable of objective assessment' and whether there exists a 'nexus' between the need identified and the imposition of differential tariff treatment is likely to be a more difficult threshold to overcome with regard to the inclusion of certain of the multilateral conventions on environmental protection. While environmental protection has been identified as an element of development, ${ }^{130}$ what is likely to cause concern is the objective logic behind the inclusion of some of the conventions listed and whether or not they

\footnotetext{
125 Özden and Reinhardt, The Perversity of Preferences: The Generalized System of Preferences and Developing Country Trade Policies, 1976-2000 (World Bank Policy Research Working Paper 2955, 2003).

126 Appellate Body Report, United States-Import Prohibition of Certain Shrimp and Shrimp Products, WT/DS58/AB/R, adopted 61998, n 107.

127 ibid para 129.

128 EC-Tariff Preferences Appellate para 94.

129 See discussion, $n 99$ et seq.

130 See, eg, the Rio Declaration on Environment and Development, UN Doc A/CONF.151/26 (vol I); 31 ILM 874 (1992) Art 4.
} 
merely pay lip service to the aim of environmental protection. The Cartagena Protocol on Biosafety to the Convention on Biological Diversity has, for example, been described as 'open to influence by a broad range of protectionist interests that have nothing to do with the protection of the environment'. ${ }^{131}$ It is contended that significant negative externalities exist with regards to the inclusion of the Cartagena Protocol on Biosafety (CPB) ${ }^{132}$ as one of the relevant conventions under the additional preferences scheme offered by the European Communities. ${ }^{133}$ The Cartagena Protocol lay at the centre of the WTO dispute of $E C$-Biotech ${ }^{134}$ which concerned complaints by the United States, ${ }^{135}$ Canada, ${ }^{136}$ and Argentina ${ }^{137}$ regarding the Biotech regulatory regime of the European Communities. ${ }^{138}$ It was the contention of the European Communities that the interpretation of the relevant WTO agreements of measures to preserve biodiversity should be consistent with the CPB. ${ }^{139}$ The United States is not a party to the CPB and argued that measures to preserve biodiversity should be in compliance with the WTO Sanitary and Phyto-Sanitary (SPS) Agreement. ${ }^{140}$

The second issue contested in EC-Biotech related to the permissibility of the 'precautionary principle'. ${ }^{141}$ The CPB is founded upon the 'precautionary principle ${ }^{142}$ and the European Communities sought to rely on this within the context of the dispute. The United States has stated its opposition to the use of this principle on numerous occasions. ${ }^{143}$

131 Hobbs, Hobbs, and Kerr, 'The Biosafety Protocol: Multilateral Agreement on Protecting the Environment or Protectionist Club?' (2005) 39(2) Journal of World Trade 281.

132 Cartagena Protocol on Biosafety, 39 ILM 1, 27 (2000).

133 Council Regulation (EC) 980/2005 Annex III.

134 Panel Reports, European Communities-Measures Affecting the Approval and Marketing of Biotech Products, WT/DS291/292/293, adopted 21 Nov 2006 (hereinafter EC-Biotech Panels).

135 Request for the Establishment of a Panel by the United States European Communities-Measures Affecting the Approval and Marketing of Biotech Products, WT/DS/ 291/23 (8 Aug 2003).

${ }^{136}$ Request for the Establishment of a Panel by Canada, European Communities-Measures Affecting the Approval and Marketing of Biotech Products, WT/DS/292/17 (8 Aug 2003).

137 Request for the Establishment of a Panel by Argentina, European Communities-Measures Affecting the Approval and Marketing of Biotech Products, WT/DS/293/17 (8 Aug 2003).

138 The DSB established a single panel to hear the complaints of all three parties at its meeting on 29 August 2003. The Panel was composed on 4 March 2004, see URL < http://www. wto.org/english/tratop_e/dispu_e/cases_e/ds293_e.htm > (last accessed 1 Sept 2006).

139 EC-Biotech Panels paras 4.300 et seq.

140 See US Oral Statement at the First Meeting of the Panel (2 June 2004) < http://www. ustr.gov/assets/Trade_Agreements/Monitoring_Enforcement/Dispute_Settlement/WTO/Dispute_ Settlement_Listings/asset_upload_file395_5542.pdf $>$ (last accessed 25 Feb 2007).

141 There are numerous understandings accorded to the precautionary principle, however, Art 1 to the CBD explicitly references Principle 15 of the Rio Declaration which states that 'in order to protect the environment, the precautionary approach shall be widely applied by States according to their capability. Where there are threats of serious or irreversible damage, lack of full scientific certainty shall not be used as a reason for postponing cost-effective measures to prevent environmental degradation', UN Doc A/CONF.151/26 (vol I); 31 ILM 874 (1992).

142 Cartagena Protocol Art 11.8.

143 Report of the Appellate Body European Communities-Measures concerning Meat and Meat Products, WT/DS26/AB/R and WT/DS48/AB/R, adopted 16 Jan 1998, 17. 
The Panel ultimately found against the European Communities. ${ }^{144}$ The relevance of the dispute to our analysis lies in the positive act of the European Communities in including the Cartagena Protocol within the confines of its GSP additional preferences. The inclusion of the CPB may lead to negative externalities with regard to certain developing countries which have signed free trade agreements [FTA] with the United States ${ }^{145}$ which include provisions to the effect that SPS measures may only be taken on the basis of scientific measures, thereby rejecting the use of the principle of precaution. Given that the relationship between the CPB and the WTO SPS Agreement is still somewhat disputed, is it appropriate for the EC to include it as one of the conventions requiring ratification for developing countries to benefit from the special incentives mechanism of the GSP?

'Precautions in the field of biotechnology' ${ }^{146}$ have been termed by the former DG Trade, Pascal Lamy, to be within the 'collective preferences' of the EC. ${ }^{147}$ Collective preferences relate to the 'end result of choices made by human communities that apply to the community as a whole'. ${ }^{148}$ The duty to safeguard collective preferences is listed as being a 'sovereign duty" 149 of all political systems. By including the Cartagena Protocol within the context of the GSP, is the EC simply exporting its collective preferences abroad to the detriment of other trading partners such as the US? In addition, if the protection of collective preferences lies within the sovereign duty of all states, then what of the sovereignty of developing nations to decide their own regulatory regime for products of biotechnology? ${ }^{150}$

In the same regard, concern has been expressed that the United States has been pressurizing smaller countries such as Sri Lanka, Croatia and Thailand to prevent them from implementing strict regulatory systems for genetically modified organisms [GMO]. ${ }^{151}$ Given that the United States is the largest exporter of products of biotechnology, the United States Trade Representative has been under immense scrutiny from biotech interest groups to ensure open markets for such goods. ${ }^{152}$ In relation, the previous United States Trade

144 EC-Biotech Panels, 303-7.

145 MC Cordonier, 'The WTO, RTAs and Sustainable Development' in L Bartels and F Ortino (eds), Regional Trade Agreements and the WTO Legal System (OUP, Oxford, 2006) 330.

${ }_{146}$ Pascal Lamy, 'The Emergence of collective preferences in international trade: implications for regulating globalisation', speech made at conference on 'Collective preferences and global governance: what future for the multilateral trading system' (15 Sept 2005) < http:// ec.europa.eu/archives/commission_1999_2004/lamy/speeches_articles/spla242_en.htm > (last accessed 31 Aug 2006).

148 ibid.

147 ibid. with Varanda Shiva' Euractiv (8 with Varanda Shiva' Euractiv (8 Mar 2004) < http://www.euractiv.com/en/trade/full-interviewvandana-shiva-ills-world-trading-system/article-117411 > (last accessed 1 Sept 2006); see also S Charnovitz, 'An Analysis of Pascal Lamy's Proposal on Collective Preferences' (2005) 8 Journal of International Economic Law 449.

151 BRIDGES/ITCSD 'US Steps Up Pressure Over Biotech Rules' (20 Sept 2001) < http: //www.ictsd.org/biores/01-12-20/story2.htm > (last accessed 23 Feb 2007).

152 Thailand threatened with s 301 action for its labelling regime in regard to GMOs. 
Representative (USTR) Robert Zoellick has sought to link biotech with development issues stating that the biotech area is

extremely important in terms of dealing with (issues) ranging from the hundreds of millions of African children who have malnutrition to extreme possibilities for benefits in terms of growing food with fewer fertilizers and pesticides. $^{153}$

In addition, the enactment of the 'United States Leadership Against HIV/AIDS, Tuberculosis and Malaria Act' ties funding to fight HIV/AIDS with acceptance of GM food. ${ }^{154}$

The GMO debate has been described as 'cold war' between GMO pessimists such as the EC, and GMO optimists such as the United States. ${ }^{155}$ This GMO cold war has

placed strong pressures on developing countries to choose sides, undermining their abilities to make independent judgements and choices with regard to whether or how GM biotechnologies fit their particular circumstances.

This stress upon developing countries 'choosing' sides can only serve to undermine their independence and autonomy to make strategic choices regarding their agricultural development and whether their needs mandate the use, or indeed non-use, of GMOs. ${ }^{156}$

With regard to the inclusion of the $\mathrm{CBD}$ as one of the multilateral agreements requiring ratification under the EC GSP special incentives arrangements, it could be argued that its selection represents the pursuit of European values of pessimism towards GM? To expand, could the relevant 'development, financial or trade' need to which the grant of preferences is intended to respond be skewered in such a way as to promote the preference granting state's interests? It is notable that the Appellate Body does not make more of the input of the GSP recipient state with regard to discerning the existence of a relevant 'developmental, financial or trade need'.

Rather, the Appellate Body held that ' $[\mathrm{b}]$ road-based recognition of a particular need, set out in the WTO Agreement or in multilateral instruments adopted by international organizations can act as this standard' (emphasis added). ${ }^{157}$

It is noted that the operative word in the Appellate Body's statement is the word 'can' and not 'shall'. It would appear that multilateral recognition in the form of legal instrument or international treaties is not definitively necessary and that developed country donors are largely 'self policing' in delineating the

\footnotetext{
153 Cited in BRIDGES/ICTSD 'US Pressures WTO Members on GMOs' (24 Jan 2002) $<$ http://www.ictsd.org/biores/02-01-24/story1.htm > (last accessed 23 Feb 2007).

${ }^{154}$ E Meijer and R Stewart, 'The GM Cold War: How Developing Countries Can Go from Being Dominos to Being Players' (2004) 13(3) Review of European Community and International Environmental Law 247, 253.

155 ibid 252 .

157 EC-Tariff Preferences Appellate (n) para 163. 
development, financial or trade 'need' to be addressed. ${ }^{158}$ Schaffer and Apea have remarked that the relative autonomy of developed country donor states to discern the relevant 'need' creates a situation in which 'developing countries are seriously affected by ... EC decisions without having much impact into the decision-making process'. ${ }^{159}$

With regards to the various agreements relating to environmental protection contained in the GSP offer of the EC, it is difficult to discern the reasons why those particular agreements were chosen. There are over 250 MEAs currently in existence. This vast proliferation of international concern for environmental protection has created a situation in which both developed and developing countries have to assess and prioritize the requisite advantages and demerits of each agreement. Each state is sovereign and will ultimately have a better conception of their own needs than outside observers. However, within the context of the GSP, it has been demonstrated that the assessment of 'need' to which measures of GSP positive conditionality are intended to respond lies solely with the GSP granting state. While the GSP is a 'unilateral' trade instrument, the autonomy of the granting state to designate need may serve to undermine the mechanism of the GSP as a tool with which to effect development. The position of the GSP granting state as the sole arbiter (with appropriate evidence, where applicable, from international bodies) of what constitutes need lies in stark contrast to the Panel's findings in BrazilAircraft ${ }^{160}$ which upheld the right of a developing country to assess their own development needs. In considering the question of whether export subsidies granted by Brazil to foreign purchasers of Brazil's Embraer aircraft, the Panel (and to a lesser extent the Appellate Body) showed considerable deference ${ }^{161}$ to the ability of Brazil to identify its own development needs. In doing so, the Panel stated that

an examination as to whether export subsidies are inconsistent with a developing country member's needs is an inquiry of a peculiarly economic and political nature, and notably ill-suited to review by a panel whose function is primarily legal. ${ }^{162}$

While Brazil-Aircraft dealt with the special and differential treatment (SDT) provisions of the Subsidies and Countervailing Measures (SCM) Agreement, SDT is part of the regime established by the Enabling Clause to secure the economic development of developing states and thus the substantive divisions between the EC-Tariff Preferences case and that of Brazil-Aircraft are not as

158 Shaffer and Apea, 'Institutional Choice in the General System of Preferences Case: Who Decides the Conditions for Trade Preferences? The Law and Politics of Rights' (2005) 39 Journal of World Trade 977, 996.

160 Panel Report, Brazil-Export Financing Programme for Aircraft, WT/DS46/R, adopted 20 Aug 1999 (hereinafter Brazil-Aircraft).

${ }_{161}$ For a discussion on this point, see Footer, 'Developing Country Practice and WTO Dispute Settlement' (2001) 35 Journal of World Trade 55, 87.

162 Brazil-Aircraft, para 7.89. 
substantial as they would at first appear. While one must always be careful to compare like with like, surely the precedent in Brazil-Aircraft to the effect that developing countries should have autonomy to assess their own development needs should be applicable to other cases under the Enabling Clause and SDT measures more specifically.

In a recent Commission White Paper on the subject of 'Opening the Door to Development', note is made of the importance of European markets to developing countries.

EU preferential systems, either unilateral (GSP) or based on bilateral and regional agreements (Economic Partnership Agreements and Free Trade Areas) also have at their heart European values, as, more and more, developing countries that base their internal governance on high social and environmental standards will have better access to our market (emphasis added). ${ }^{163}$

Similarly, in a speech to the European Parliament in 2001, the Commission made clear that the drug arrangements offered under the then current GSP would be part of a quid pro quo for European values and investment. In essence, the Latin American countries offered GSP concessions under the Drug Arrangements would be expected 'to respond to the special access we are offering them to the European market by promoting foreign - and in particular European-direct investment, tackling corruption and battling for social justice'. 164

The promotion of values through the GSP can be contextualized within the much wider debate as to the normative frame through which one should view the exercise of global governance. ${ }^{165}$ Should we view the GSP through a normative frame which sets the promotion of values such as 'good governance' and 'sustainable development' as preeminent or should trade liberalization and market access be depicted as the dominant factor? The problem, for one commentator, is that a

normative frame based on a dichotomy of trade liberalization goals and 'American' and European 'values' reflected in preference schemes ignores that others around the world see themselves neither in a 'free trade' camp nor an American value camp. They rather distrust the language of 'American values' because it can camouflage the pursuit of 'American interests' in relation to developing countries. ${ }^{166}$

In the same way, the pursuit of European 'collective preferences' via the GSP may impact negatively upon developing country recipients. The use of trade

163 Commission White Paper on Opening the Door to Development: Developing Country Access to EU Markets 1999-2003 (23 May 2005) < http://rade.ec.europa.eu/doclib/docs/ 2005/august/tradoc_123305.pdf > (last accessed 25 Feb 2007).

164 Speech to the European Parliament on 'The Community 2002-2004 GSP: An Instrument of Sustainable Development' Strasbourg (12 June 2001) < http://trade.ec.europa.eu/doclib/docs/ 2004/october/tradoc_119427.pdf $>$ (last accessed 25 Feb 2007).

165 Shaffer and Apea (n 158). 
measures to promote sustainable development should therefore aim to promote cooperation and multilateral, as opposed to unilateral, values.

\section{CONCLUSION}

The link between trade and environmental protection has long been a contentious one. It has been pointed out that the WTO is primarily a trade organisation and while the Uruguay Round culminated in the establishment of a Committee on Trade and the Environment (CTE), this has failed to accomplish anything beyond acting as a mere talking shop in relation to environmental matters. It has been singularly unsuccessful in fulfilling its twotiered mandate to make recommendations as to whether any modifications are needed to the existing WTO system and identify the relationship between trade measures and environmental measures ${ }^{167}$ in relation to the pursuit of sustainable development. ${ }^{168}$

Thus, despite the fact that many multilateral environmental agreements (MEAs) contain allowance for trade measures, there has been no decisive or coherent statement emanating from the WTO as regards to the relationship between the two. There is also the issue that many MEAs have their own dispute settlement mechanisms raising the spectre of parties 'forum shopping, ${ }^{169}$ in order to find the body that will deliver the most favourable outcome. Such a situation does not serve to create coherence within the system of environmental governance. Indeed, the interaction between MEAs and the WTO is reflected by the fact that several of the more recent environmental agreements use language from the GATT in their approach to restrictions on trade. $^{170}$

There have been numerous statements emanating from within the WTO and various member countries that it is not the forum within which to discuss environmental issues. For example, in 2001 three former Director-Generals of the WTO issued a statement to the effect that, "the WTO cannot be used as a Christmas Tree on which to hang any good cause that may be secured by exercising trade power'. ${ }^{171}$ Such views have taken on particular resonance in

167 See WTO Doha Ministerial Declaration para 31 (i) calling for negotiations to explore 'the relationship between existing WTO rules and specific trade obligations set out in multilateral environmental agreements (MEAs' WTO Doc WT/MIN(01)/DEC/1.

168 S Shaw and R Schwartz, 'Trade and the Environment in the WTO: State of Play' (2002) 36 Journal of World Trade 129, 130.

169 D Brack and K Gray, Multilateral Environmental Agreements and the WTO, paper presented to the IISD/RIIA Workshop on Trade and Sustainable Development Priorities Post Doha, London, 7-8 Apr 2003, 28.

170 D Brack and T Branczik, Trade and Environment in the WTO: After Cancun (Royal Institute of International Affairs, London 2004).

${ }^{171}$ As cited in S Charnovitz, 'Triangulating the World Trade Organisation', (2002) 96 American Journal of International Law 28, 29. 
light of cases heard within the WTO Dispute Settlement Body such as the socalled Shrimp-Turtle ${ }^{172}$ dispute.

The view that the WTO is not the place for discussing issues pertaining to the environment loses potency when one considers that the environment, through its link with sustainable development, has always been part of the remit and thus the system of values inherent within the WTO. ${ }^{173}$ Indeed, more recent statements from the current Director General of the WTO, Pascal Lamy, reveal something of a more enthusiastic approach to dealing with environmental concerns within the auspices of the WTO. ${ }^{174}$ The dispute of EC-Tariff Preferences introduced into the jurisprudence of the WTO the idea that 'development' is an evolutionary concept encompassing 'sustainable development'. ${ }^{175}$ Concern for the development of less developed countries therefore can include matters such as environmental protection. However, the pursuit of environmental protection and development through trade should aim to promote cooperation and multilateral values.

With regard to the current GSP scheme of the European Communities, it has been demonstrated above that the requirement for beneficiary seeking developing countries to ratify the Cartagena Protocol on Biosafety may owe much to a concern for the promotion of European 'values.' In this regard, it should be noted that the Kyoto Protocol to the United Nations Framework Convention on Climate Change has also been included as one of the conventions requiring ratification under the 'special incentives' scheme. The Kyoto Protocol has been the scene of recent clashes between the European Communities and the United States with the former French premier, Jacques Chirac, recently proposing to issue a 'border tax adjustment' upon goods which are produced by countries which have not signed up to Kyoto. ${ }^{176}$ The European Communities has been exerting considerable pressure on third countries to sign up to the Kyoto, as evidenced by media reports which have suggested that European support for Russian accession to the WTO was made dependent upon Russian support for Kyoto. ${ }^{177}$ While efforts to address the problem of climate change are needed ever more urgently, countries granting GSP concessions should avoid the use of the GSP as a tool with which to pursue values of importance to them. In assessing the existence of a relevant

\footnotetext{
172 Appellate Body report of United States-Import Prohibition of Certain Shrimp and Shrimp Products, WT/DS58/AB/R, adopted 61998.

${ }^{173}$ See WTO Ministerial Declaration (n 167) para 6 which notes that Members 'strongly reaffirm our commitment to the objective of sustainable development, as stated in the Preamble to the Marrakesh Agreement'.

${ }^{174}$ Speech by Pascal Lamy, 'Lamy Urges Support for environmental chapter in the WTO' (5 Feb 2007) < http://www.wto.org/english/news_e/sppl_e/sppl54_e.htm > (last accessed 28 Feb 2007).

${ }^{175}$ See discussion (n 129) et seq.

176 Bennhold, 'France Tells US to Sign Climate Pact or Face Tax' New York Times, New York, 1 Feb 2007.

177 McCarthy et al, 'Russia Finally Backs Kyoto: Does it Matter?' The Independent, London, 1 Oct 2004.
} 
need to be addressed by measures of conditionality in the GSP, the Appellate Body in any future dispute should place more emphasis upon the involvement of developing country recipients of tariff concessions in assessing their own needs. While the GSP is inherently a 'unilateral' trade instrument, any conditionality should reflect a genuine 'partnership for development'.

In a similar vein, it has been demonstrated that the requirement of ratification by 2008 of all 27 conventions listed in the GSP regulation may be overly burdensome to certain eligibility-seeking countries. As such, the ratification requirement may have a 'disparate impact' upon individual countries such as to breach the obligation that the additional preferences are available to all similarly situated countries sharing the same need. This article calls for the European Communities to assess the 'impact' of the ratification requirement upon each of the countries concerned. Such an assessment would be in line with the recent efforts of the European Communities to introduce 'sustainability impact assessments' into its trade agreements. ${ }^{178}$

178 Communication from the European Commission on Impact Assessment, COM(2002)276 final (not published in the Official Journal). 